\title{
NATURAL CAPITAL PRESERVATION AND SUSTAINABLE MANAGEMENT AS A PREREQUISITE FOR YEAR-ROUND TOURISM
}

\author{
Lidija Runko Luttenberger*, Ivana Gudelj ${ }^{* *}$ \\ * University of Rijeka, School of Polytechnics, Rijeka, Croatia \\ ${ }^{* *}$ Ministry of Environment and Energy, Zagreb, Croatia
}

corresponding author: Lidija Runko Luttenberger, e-mail: lidija.luttenberger@uniri.hr

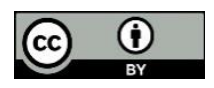

This work is licensed under a

Creative Commons Attribution 4.0

International License

Review paper

Received: April 11 ${ }^{\text {th }}, 2019$

Accepted: May 31 ${ }^{\text {st }}, 2019$

HAE-1912

https://doi.org/10.33765/thate.9.3.3

\begin{abstract}
Increasing number of tourists wants to experience nature and at the same time have a positive impact on nature during their tourist stay. This paper presents the relationship between the preservation of natural capital of the locality and tourist season duration, as well as destination sustainable management and longevity. Tourism greatly depends on natural world, meaning the beauty of landscapes and seascapes and man's connection with nature itself. It simultaneously depends on local natural environment and exerts an impact thereon. Conservation and sustainable management of natural capital maybe achieved in various ways. Countries are attempting to preserve natural capital and to monitor its change through regular reporting, using selected indicators. Croatia should strive to preserve its unique natural resources and devise the tools to measure own performance with due consideration of its specific feature, all with the aim of ensuring sustainable all-year tourism. Finally, the paper considers comprehensively all pressures on natural environment exerted by tourism as well as benefits for the locality of preserving domestic natural capital in a long term, while ensuring the monitoring of changes in state thereof. A 'high value, low impact' approach would bring in the growing share of affluent nature-loving tourists throughout the year, thus reducing present tourism seasonality and highly negative impact on nature, local communities and microclimate change.
\end{abstract}

Keywords: natural capital, tourism, sustainable management, impact on nature, year-round tourism

\section{INTRODUCTION}

Natural capital consists of living and nonliving environmental resources that are potentially available to generate value and constitute national richness, as it provides valuable goods and services to people such as clean air, clean water, food and recreation. Reckless development harms the environment, degrades scenery, disrupts local culture, and directs tourism revenues away from local communities. In addition, growing number of 
affluent, educated and environmentally conscious visitors avoid certain places for being too touristy [1].

Basic resource at disposal in Croatia is a diverse and still relatively well-preserved nature. Apart from ecosystem services [2], natural resources - their beauty and biodiversity - are crucial for tourism which is responsible for $20 \%$ of national GDP [3]. Various countries endeavour to value and monitor their natural capital and report thereon, for instance Italy [4] or United Kingdom [5]. Croatia also makes efforts with regard to fulfilling its international obligations in that respect [6]. Nevertheless, in spite of the fact that Croatia is among leading EU countries with regard to biodiversity, that invaluable resource is not sufficiently acknowledged, manifested and interwoven into nation's pride.

The paper presents trends in demand of present-day tourism, reviews the status of ecosystems and protected areas in Croatia, analyses the pressures on nature exerted by tourism industry, discusses the instruments in tourism management, and provides the proposals for practicing sound year-long tourism without nature as its main lasting asset being subject to exhaustion.

\section{PRESENT-DAY TOURISM REQUIREMENTS}

Domestic and foreign tourists want to experience the distinctive natural, indigenous and historic places and the rich stories associated with them. Successful tourism at heritage places involves recognizing the importance of heritage places that must be considered by tourism operators, heritage managers, communities, and others who need to understand the issues involved in the relationship between tourism and heritage places. Also looking after heritage places, developing mutually beneficial partnerships, incorporating heritage issues in business planning, investing in people and place, marketing and promoting products responsibly, providing high quality visitor experiences, as well as respecting Indigenous rights and obligations [7].

According to UNESCO report [8] behavioural aspects of present-day tourism are the following: increased awareness for the environment, increased travel experience, higher consciousness of quality and value for money and more selected choice of destination. Tourists have also become much more physically and intellectually active, they look for new destinations and new tourism products, and want to visit places that are environmentally friendly and respect social justice. Older people and disabled people are travelling more, there is an increase in use of IT, more tourism destinations are adopting the planned and managed approach to developing tourism, wishing to develop good quality sustainable tourism, and more frequent but shorter holidays are taken throughout the year. With regard to activities, more and more tourists wish to participate in recreation, sports and adventure and to learn about culture history and the natural areas of the places visited, forms of adventure tourism are expanding rapidly as are also other specialized forms of tourism including cultural, nature, 'roots', health and religious tourism. In addition, culture and ecotourism are being increasingly developed as a way to protect the natural beauty and cultural heritage of an area, and there is a significant increase in health and spa tourism.

The report furthermore states that tourists appreciate a healthy and beautiful natural environment and reject destinations where the pollution and destruction of the natural environment takes place. Sustainable tourism is taking its sources from the region's own attractions and past - not from something brought in from abroad, like e.g. a fully air conditioned tropical greenhouse-landscape in a northern region or an indoor ski park in a region where there is never enough natural snow for skiing. The natural and cultural heritage of a region is the main motivation for a tourist's visit, providing at least an important 
complementary offer for other types of tourism, e.g. congress tourism, recreation and sports tourism. The outstanding natural and cultural features of a region are those factors which make a place "special" - and worth a visit. Natural heritage itself consists not only of flora and fauna, but also of every other part of the natural environment, e.g. the inorganic nature such as rocks, geologic formations, rivers, lakes, mountains as well as the relation between these natural components as ecosystems. The main components of the natural heritage are vegetation and wildlife, geology, hydrology and natural phenomena. Also 'events', such as climate, volcanic or astrological incidents, the course of the year, evolution and the changes in the ecosystems are part of natural heritage. Besides their importance as tourism attractions, each component of natural heritage may be a topic of educational and scientific interest.

Therefore, more and more tourists want to have a positive impact associated with their tourist dollars [9]. Appropriate approach to protection of natural attractions, in other words, promoting the preservation of attractions in the destination, may only increase the chances of securing more even distribution of higher number of tourist visits throughout the year.

\section{ECOSYSTEMS AND PROTECTED AREAS IN CROATIA}

In Croatia, there are 408 protected areas within nine national protection categories, comprising $8.62 \%$ of the total national territory, Table 1 .

The study entitled Mapping and assessment of ecosystems and their services in Croatia [10] represents the first study in this field elaborated at national level. The study produced the Ecosystems map where 39 CORINE Land Cover (CLC) classes represented in Croatia are reinterpreted into 71 ecosystem types pursuant to EUNIS habitat classification, Figure 1.
Information on the status of the particular habitat types in Croatia are modest. In the process of producing the Map of terrestrial non-forest habitat types, data on representation and distribution have been collected [11]. Aforementioned map shows relatively favourable state of non-forest habitats in Croatia, but also indicates the problems concerning stability of marine coastal habitats characterized by the least share of highly represented species, an indicator of how much „typical“ is habitat type in a particular area, or how many typical species are present thereon. Insignificant representation means that degraded forms of habitats are present. Coastal ecosystems are indeed subject to exceptional pressure from tourism-related activities.

Natura 2000 is the basic mechanism for nature protection in the European Union the objective whereof is, through the establishment of ecological network, to contribute to conservation of favourable state of more than thousand animal and plant species and about 230 habitat types listed in annexes of the Habitats Directive (EU 1992) and Birds Directive (EU 2009). Ecological network of Croatia was proclaimed under the Regulation on Ecological Network [12] and its amendments [13], and it is integrative part of the ecological network of the European Union Natura 2000.

Ecological network of Croatia shown in Figure 2 covers $36.73 \%$ of continental territory and $15.42 \%$ of the sea, as well as $9.81 \mathrm{~km}^{2}$ of the area outside the territorial sea under national jurisdiction. It consists of 743 Areas significant for conservation of species and habitat types and 38 Areas significant for preservation of birds [14].

Considering the share of ecological network in total area of Croatia, there are differences with regard to Continental and Alpine (karst) biogeographical regions of Croatia. Karst is particularly rich in biodiversity and is recognized as one of the most important areas of nature conservation in Europe, therefore in its percentage of Natura 2000 it significantly transcends European average of 18.17 \% (EU 
2018), that being obvious since Natura 2000 areas are singled out for their biodiversity abundance. Such a picture is also reflected in percentages of Nature 2000 network covering the areas in particular counties. For instance, in Primorsko-Goranska County, the ecological network covers about $75 \%$ of terrestrial part of the county. The reason for that are vast preserved forest ecosystems that sustain the presence of three large carnivores (wolf, bear and lynx) as well as a whole series of forest bird species.

Table 1. Protected areas in Croatia [15 - 17]

\begin{tabular}{|c|c|c|c|c|c|}
\hline $\begin{array}{c}\text { National } \\
\text { categories }\end{array}$ & $\begin{array}{c}\text { Number of } \\
\text { protected } \\
\text { areas }\end{array}$ & $\begin{array}{c}\text { Absolute } \\
\text { area }\left(\mathrm{km}^{2}\right)\end{array}$ & $\begin{array}{c}\text { Actual } \\
\text { area }\left(\mathrm{km}^{2}\right)\end{array}$ & $\begin{array}{c}\text { Share in total } \\
\text { protected area } \\
(\%)\end{array}$ & $\begin{array}{c}\text { Share in area of } \\
\text { national territory } \\
(\%)\end{array}$ \\
\hline Strict Reserve & 2 & 24.13 & 24.13 & 0.32 & 0.03 \\
\hline National Park & 8 & 979.63 & 966.66 & 12.72 & 1.10 \\
\hline $\begin{array}{c}\text { Special } \\
\text { Reserve }\end{array}$ & 77 & 399.48 & 396.61 & 5.22 & 0.45 \\
\hline Nature Park & 11 & 4320.48 & 4023.42 & 52.94 & 4.56 \\
\hline Regional Park & 2 & 1025.56 & 1018.48 & 13.4 & 0.00 \\
\hline $\begin{array}{c}\text { Nature } \\
\text { Monument }\end{array}$ & 80 & 2.27 & 2.11 & 0.02 & 1.28 \\
\hline $\begin{array}{c}\text { Significant } \\
\text { Landscape }\end{array}$ & 82 & 1330.59 & 1130.27 & 14.87 & 0.03 \\
\hline Forest Park & 27 & 29.55 & 29.52 & 0.39 & 0.01 \\
\hline $\begin{array}{c}\text { Monument of } \\
\text { Park }\end{array}$ & 119 & 9.90 & 9.4 & 0.12 & 8.62 \\
\hline Architecture & 408 & 8121.59 & 7600.61 & 100 & \\
\hline Total & \multicolumn{2}{|l}{} &
\end{tabular}

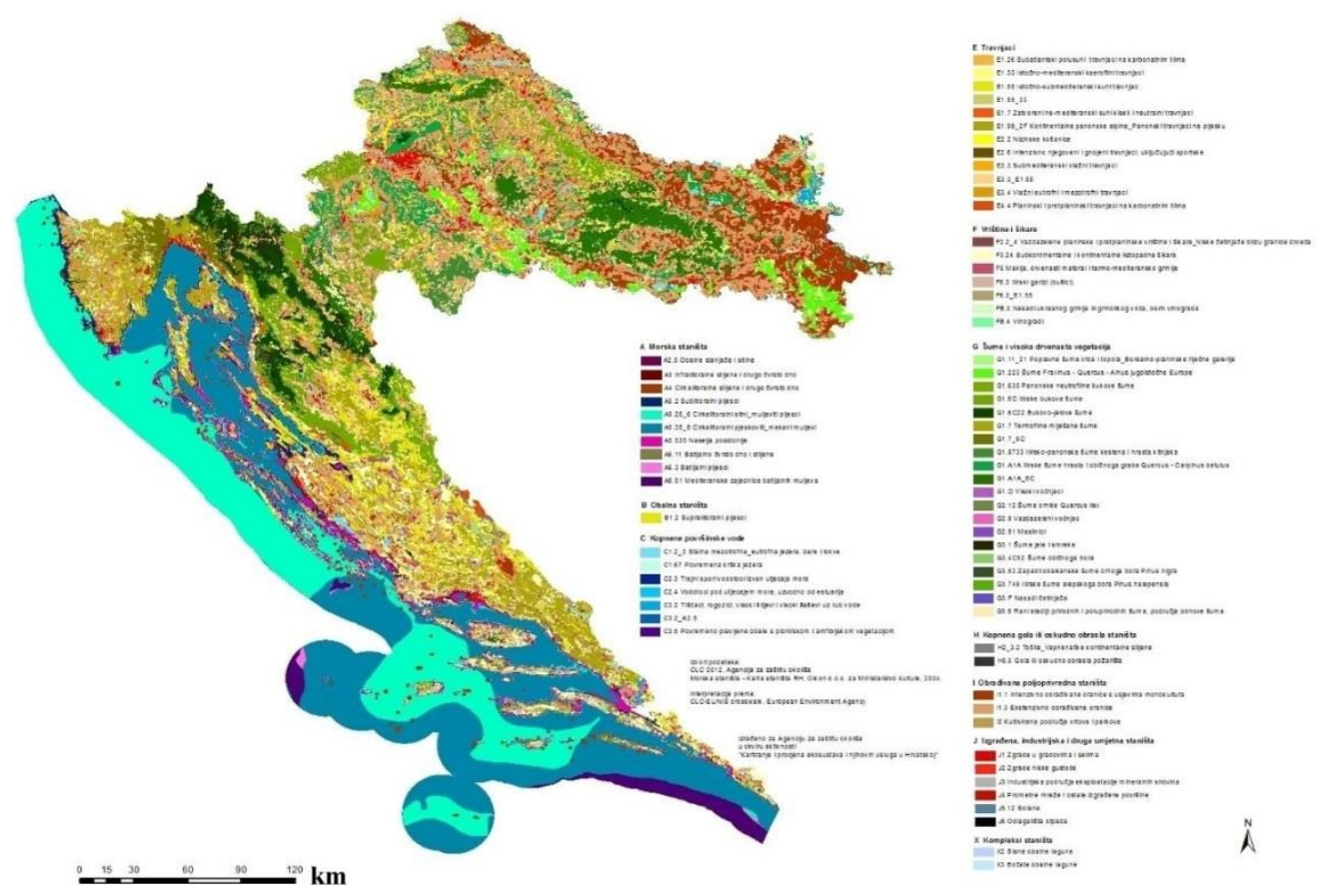

Figure 1. Ecosystems map of Croatia [18] 


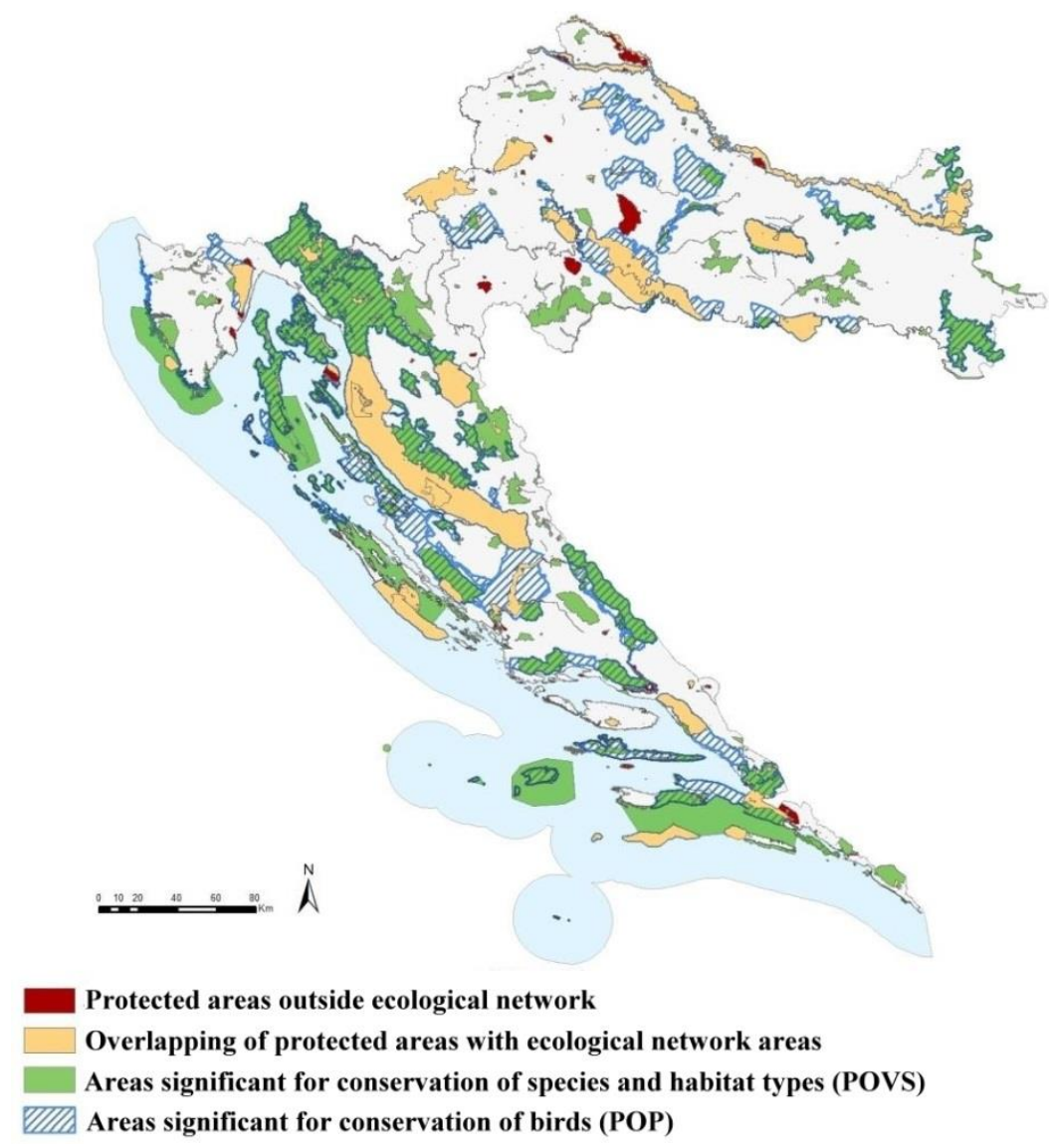

Figure 2. Map showing the protected areas and areas of ecological network

Natura 2000 in Croatia [19, 20]

\section{PRESSURES FROM TOURISM INDUSTRY}

Negative impacts of tourism involve those resulting from touristic development (e.g. hotels, resorts, marinas, roads) and from the tourists themselves. Some of the most pertinent ecological impacts in coastal areas are as follows [21]:

- loss of terrestrial and freshwater habitats caused by clearing of vegetation for site preparation and changed land use in the surrounding environment,

- loss of habitats in offshore areas caused by dredging or reclamation works, construction of berthing facilities and marinas, changed circulation patterns caused by water-based facilities, by the earthworks on land near the shoreline for industrial, land, ports, airports, roads and recreational facilities resulting in siltation and construction runoff, and anchor damage from large cruise ships and other vessels,

- decline in water quality, eutrophication caused by sewage discharges,

- presence of hazardous substances in seawater,

- shadow and lighting,

- noise (underwater and above water),

- visual impact upon shoreline areas,

- development in scenic and pristine coastlines,

- significant use of ozone depleting substances by refrigerators, air conditioners, propellants and emissions from jet aircraft,

- climate change.

It is estimated that nature in Croatia is mostly threatened by human activities, precisely by modifications of natural ecosystems, exploitation of biological resources and pollution. With regard to individual causes 
associated with tourism, particularly problematic are municipal wastewaters, waste management, water supply [22], transport infrastructure, as well as the construction of touristic and recreational areas. Human activities mostly result in loss, fragmentation, and degradation of habitats.

According to Gössling et al [23], coastal zones are under threat, often because of tourism. In many areas, the impacts compound each other to a degree where tourism systems are no longer viable or have to be maintained with considerable financial effort or at lower profit margins. Coastal tourism consequently requires to be managed in sustainable ways, considering interrelationships between local and non-local resource use, ecosystem change and climate change. Coastal management should address a range of issues, including spatial planning with short- and long-term perspectives, in which ecosystem functioning and ecosystem services are of central relevance.

\section{TOURISM MANAGEMENT AND GOVERNANCE}

Regardless of the term used in designating specific relationship between tourism and natural heritage: nature-based tourism, environmental tourism, eco-tourism, wildlife tourism, adventure tourism or other, the fact is that tourism industry itself represents a pressure on environment and its management must be addressed properly moreover reasonably.

The activities related to visitor management are markedly intensified as in all public entities that manage the parks the number of visitors in certain periods represents a severe pressure on natural values of protected area, as well as the capacities of public entities.

Through system-type projects in the sector (Croatia EU Natura 2000 Integration Project NIP and Strengthening the Institutional and Financial Sustainability of the National
Protected Area System - PARCS) numerous activities have been undertaken along with enhanced visibility and branding of national and nature parks. Visual identity of parks was designed, and the system of signalization and interpretation prescribed in the Ordinance, along with website Parks of Croatia, mobile applications with interactive map as well as appropriate communication on social networks.

In addition, Marketing Strategy - Parks of Croatia [24] was drafted with the aim to attract to the national and nature parks a different, environmentally more responsible visitors' profile and promote the visiting of less visited areas.

In Nature Protection Strategy and Action Plan of the Republic of Croatia for 2017-2025 period [25], sustainable development is mentioned within the context of Strategic goal 5: "Raise the level of knowledge, understanding and public support for nature protection". It states that through the operations of public institutions the energy efficiency should be promoted, green building, waste prevention, collecting and separating waste, as well as sustainable tourism.

One of the most prominent mechanisms for preservation of ecological network is the appropriate assessment procedure. Pursuant to Article 6 of the Habitats Directive, appropriate assessment is compulsory for any plan or project that by itself or in combination with other plans or projects may have a significant negative impact on targeted species and habitat types of the area of ecological network Natura 2000. In so doing, what is important is not siting of the project (whether it is situated within the area of ecological network or outside it), but the procedure is instituted for evaluating the potential impact on targeted species and habitat types. In Croatia, this mechanism was introduced as late as year 2008. Until mid-2013, appropriate assessment was undertaken for ecological network. The bulk of applications for appropriate assessment is resolved in the first stage of the procedure (preliminary assessment), while the most 
common types of projects for which the second stage of the procedure has been undertaken (appropriate assessment) are various projects concerning water regulation works, road infrastructure, wind farms and hydroelectric plants.

Sound and timely realization of appropriate assessment procedures with regard to ecological networks is confronted with a series of problems that may significantly aggravate the implementation of this procedure in the future. One to be singled out in particular the lack of capacities in governmental and public entities as well as insufficient quality of environmental reports drafted.

Particularly important in tourism development, and consequently physical planning, transport and utilities infrastructure is also the instrument of environmental impact assessment, or strategic environmental assessment of plans and program documents, as a part of environmental legislation.

Environmental impact assessment report to be produced in strategic environmental assessment (hereinafter: SEA) procedure must comprise the following: an outline of the contents and main objectives of the strategy, the aspects of the current state of the environment and likely evolution thereof without implementation of the strategy, the environmental characteristics of areas likely to be significantly affected, any existing environmental problems, the environmental protection objectives and the way those objectives and any environmental considerations have been taken into account during its preparation, the likely significant effects (secondary, cumulative, synergetic, short-term, mid-term and long-term, permanent and temporary, positive and negative) on the environment, including biodiversity, population, human health, fauna, flora, soil, water, air, climate, material assets, cultural and historical heritage, landscape and the interrelationship between those, the measures envisaged to prevent, reduce and abate adverse effects on the environment of implementing the strategy, the grounds for selecting reasonable alternatives dealt with, followed by separate chapter on appropriate assessment of the strategy for ecological network insofar such is being implemented within the framework of SEA procedure.

Although current Tourism Development Strategy of the Republic of Croatia [26] has not been subject to SEA as a mechanism that would render possible the perceiving of nature preservation also in the context of planning the development of other branches of tourism, mentioned procedure/mechanism was applied in drafting county tourism development plans. Furthermore, SEA procedure was completed with regard to master plans for tourism development in several counties with defined measures for preservation of biodiversity and basic values of protected areas.

An important direct mechanism of nature protection that is implemented through other sectors is incorporating the nature protection requirements and measures in management plans for particular natural resources and in physical planning documents. This mechanism has its origin in nature protection legislation, setting it out since 2003. An outstanding shortcoming of the system of nature protection measures and requirements is that it is still insufficiently known to which extent the requirements and measures secured have been taken into account when planning process for natural resource management and physical planning, and what their efficiency actually is.

Within the framework of physical planning, intensified is the implementation of strategic impact assessment, pursuant to Regulation on strategic assessment of the impact of a strategy, plan and programme on the environment [27], primarily with regard to amending county physical plans. In 2017, the Spatial development strategy of the Republic of Croatia [28] was adopted, as the first overall physical planning strategic document that underwent strategic environmental assessment procedure, within the context of which the subject of nature protection was appropriately elaborated. Strategic environmental assessment was also undertaken for certain 
county physical plans as well as for urban development plans of national significance.

In transport sector that is strongly related to tourism, in course of 2017 the strategic environmental assessment procedure has been completed for the 2017-2030 Transport development strategy of the Republic of Croatia [29] as well as for other strategic plans related to transport such as national plans for the development of ports, as well as certain county level transport development plans.

With regard to individual projects directly related to tourism development, the procedure of environmental impact assessment is carried out pursuant to Annex I, and screening procedures pursuant to Annexes II or III of the Regulation on environmental impact assessment [30]. The project related to tourism and for which the assessment procedure is implemented is building a golf course, while projects for which screening procedures are undertaken are sport and recreation centres, tourist zones, ski slopes, thematic parks, campsites and camp rest areas, as well as urban development projects (water supply systems, local roads, bike routes, etc.). The projects that are significant for tourism development, indirectly related but for which the environmental impact assessment procedure is undertaken are marine fish and shellfish farms, marine ports and airports, roads, railways, sewerage systems etc. The projects subject to screening procedures are for instance food production and processing facilities and waste landfills.

Therefore, visitors' management of protected areas, nature protection strategic document, tourism development strategic documents, appropriate assessment procedures, nature protection requirements and measures incorporated in management plans, strategic environmental assessment for plans and programs related to tourism and nature, and environmental impact assessment procedures for individual projects are all available instruments that should be used efficiently in tourism management.

\section{CONCLUSION}

Coastal areas in Croatia are subject to interventions by property developers in tourism and leisure sector, whereby intense construction activity removes natural land habitats. Such artificial areas, which are for some reason sometimes even proclaimed as being of strategic national interest, can in fact be found elsewhere worldwide and then serve mainly as reception capacities at times of seasonal excessive demand and migration to the sea. The construction of such accommodation facilities in pristine places implies also the provision of water supply, wastewater treatment and waste management facilities, road networks, which all change local landscape, consumes precious resources and discharges emissions to the air, land, water and the sea, thus impairing entire ecosystems in the area.

Based on negative experiences to date, Croatia should take a more proactive approach to preserve its natural capital paying special attention to the national parks and nature parks in the interest of its people, sustainability of its ecosystems and the economic profit that depends thereon.

Protected areas should be managed properly, but in no way be confined, leaving the outside world that is no less attractive subject to much less regulation with regard to land use, emissions and natural resource exploitation, and left to deal with the waste originating from sometimes overcrowded protected areas. More even distribution of tourists would be achieved consequently.

Particular attention should be paid to strategic planning of tourism development after 2020 . Tourism development must also be contemplated as a function of preservation of natural and cultural heritage, that to be examined by means of strategic environmental assessment that should be drafted in parallel with tourism development strategy.

Of particular significance for the development of sustainable tourism in coastal area of 
Croatia are also the considerations of acceptability for the environment and society of individual projects for which the environmental impact assessment / screening procedures are compulsory.

Many people travel in order to enjoy, explore, and appreciate nature, wishing to create unique experiences with minimum impact. Sound yearlong tourism should be practiced without nature as its main lasting asset being subject to exhaustion.

\section{REFERENCES}

[1] US Agency for International Development (2011), Tourism Destination Management: Achieving Sustainable and Competitive Results, https://rmportal.net/library/collections/gs ta/tourism-destination-managementachieving-sustainable-and-competitiveresults/view, Accessed: February 12, 2019.

[2] L. Runko Luttenberger, I. Gudelj, V. Hršak, Natural capital preservation in the coastal area, Pomorstvo 32(2018) 2, 191200.

[3] Ministarstvo turizma Republike Hrvatske (2018), Turizam u brojkama 2017, https://www.htz.hr, Accessed: February 12, 2019.

[4] Comitato per il Capitale Naturale (2018), Secondo Rapporto sullo Stato del Capitale Naturale in Italia, Roma, https://www.minambiente.it/sites/default /files/archivio/allegati/sviluppo_sostenib ile/II_Rapporto_Stato_CN_2018_2.pdf, Accessed: February 12, 2019.

[5] Natural Capital Committee (2019), State of Natural Capital Annual Report 2019 Sixth Report to the Economic Affairs Committee of the Cabinet, https://assets.publishing.service.gov.uk/g overnment/uploads/system/uploads/attac hment_data/file/774218/ncc-annualreport-2019.pdf, Accessed: February 12, 2019.
[6] Croatian Agency for Environment and Nature (2017), Usluge ekosustava, http://www.haop.hr/hr/tematskapodrucja/prirodne-vrijednosti-stanje-iocuvanje/stanista-i-ekosustavi/uslugeekosustava, Accessed: November 17, 2018.

[7] Australian Heritage Commission (2001), Successful tourism at heritage places, http://155.187.2.69/heritage/ahc/publicat ions/commission/books/pubs/successfultourism.pdf, Accessed: November 10, 2018.

[8] UNESCO (2009), Sustainable tourism development in UNESCO, http://portal.unesco.org/es/files/45338/12 417872579IntroductionSustainable_Tour ism.pdf/Introduction_Sustainable_Touris m.pdf, Accessed: November 10, 2018.

[9] CNBC (2011), Eco-tourism no longer for just the rich and fashionable - Travel Dollars 2011, https://www.google.hr/amp/s/www.cnbc. com/amp/id/42785072, Accessed:

November 10, 2018.

[10] Croatian Agency for Environment and Nature (2015), Mapping and assessment of ecosystems and their services in the Republic of Croatia, Zagreb,

http://www.haop.hr/sites/default/files/upl oads/dokumenti/03_prirodne/studije/eko sustav/Kartiranje_i_procijena_ekosustav a_ENG.pdf, Accessed: November 10, 2018.

[11] Ministry of Environmental and Nature Protection of the Republic of Croatia (2016), Terrestrial Habitat Mapping of the Republic of Croatia No. MENP/QCBS/13/04 - Final report, Zagreb,

http://www.haop.hr/sites/default/files/upl oads/dokumenti/03_prirodne/projekti/NI P-projekt_zavrsno_izvjesce.pdf, Accessed: December 31, 2018.

[12] Government of the Republic of Croatia, Uredba o ekološkoj mreži - Regulation on Ecological Network, Official Gazette $124 / 13$

[13] Government of the Republic of Croatia, Uredba o izmjenama Uredbe o ekološkoj mreži - Regulation Amending the 
Regulation on Ecological Network, Official Gazette 105/15.

[14] Croatian Agency for Environment and Nature (2010), Ecological network Natura 2000 of the Republic of Croatia, http://envi-

metapodaci.azo.hr/geonetwork/srv/hrv/c atalog.search\#/metadata/b82f3ac1-f051-

464a-8e05-b69ff303cad1, Accessed:

December 31, 2018.

[15] Croatian Agency for Environment and Nature (2018), Spatial GIS database of protected areas, http://bioportal.hr/gis, Accessed: November 10, 2018.

[16] Central register of spatial units, State Geodetic Administration (2016), https://dgu.gov.hr/registar-prostornihjedinica-172/172, Accessed: November 10, 2018.

[17] I. Župan, Patterns of protected area designations in Croatia, A master thesis submitted for the degree of Master of Sience in Management of Protected Areas at the University of Klagenfurt, Austria, 2012.

[18] Croatian Agency for Environment and Nature (2019), ENVI Atlas okoliša, http://envi.azo.hr/?topic $=6$, Accessed: December 31, 2018.

[19] Croatian Agency for Environment and Nature (2018), Register of protected areas, http://www.haop.hr/hr/baze-iportali/upisnik-zasticenih-podrucja,

Accessed: December 31, 2018.

[20] Croatian Agency for Environment and Nature (2015), Ecological network Natura, http://www.haop.hr/hr/baze-iportali/ekoloska-mreza-natura-2000,

Accessed: December 31, 2018.

[21] L. Runko Luttenberger, A. Luttenberger, Environmental assessment of externalities associated with tourist property development projects in coastal areas, Proceedings of $23^{\text {rd }}$ Biennial International Congress - Tourism \& Hospitality Industry 2016: Trends and Challenges, ed. H. Maškarin Ribarić, D. Smolčić Jurdana, Faculty of Tourism and Hospitality Management, Opatija, April 28-29, 2016, 404-417.
[22] L. Runko Luttenberger, Environmental Protection Based on Waste and Water Utility Service Management, Strojarstvo 52(2010) 6, 631-649.

[23] S. Gössling, C.M. Hall, D. Scott, Coastal and Ocean Tourism, Handbook on Marine Environment Protection, Springer International Publishing AG, Switzerland, 2018.

[24] Ministry of Environmental Protection and Energy (2017), PARCS Project, Zagreb,

https://www.parkovihrvatske.hr/docume nts/20181/311591/Projekt+PARCS++bro\%C5\%A1ura+HR/7cae552d-6b7d4dc3-b277-6049b805e737, Accessed: December 31, 2018.

[25] Strategija i akcijski plan zaštite prirode Republike Hrvatske za razdoblje od 2017. do 2025. godine - Nature Protection Strategy and Action Plan of the Republic of Croatia for 2017-2025 period, Official Gazette 72/2017.

[26] Strategija razvoja turizma Republike Hrvatske do 2020. godine - Tourism Development Strategy of the Republic of Croatia up to 2020, Official Gazette 55/2013.

[27] Government of the Republic of Croatia, Uredba o strateškoj procjeni utjecaja strategije, plana i programa na okoliš Regulation on Strategic Assessment of the Impact of a Strategy, Plan and Programme on the Environment, Official Gazette 3/17.

[28] Strategija prostornog razvoja Republike Hrvatske - Spatial Development Strategy of the Republic of Croatia, Official Gazette 106/2017.

[29] Strategija prometnog razvoja Republike Hrvatske za razdoblje od 2017. do 2030. godine - Transport Development Strategy of the Republic of Croatia for 2017-2030 period, Official Gazette $84 / 2017$

[30] Government of the Republic of Croatia, Uredba o procjeni utjecaja zahvata na okoliš - Regulation on Environmental Impact Assessment, Official Gazette 61/14, 3/17. 